\title{
THE INFLUENCE OF ELECTRONIC MARKETING STRATEGIES ON THE PERFORMANCE OF EQUITY BANK LIMITED IN KENYA
}

\author{
Rose Ndegwa ${ }^{\mathrm{i}}$ \\ Meru University, \\ Kenya
}

\begin{abstract}
:
The evolution and direction of any marketing strategy in local and international environments has forced firms to adopt electronic marketing strategies to gain competitive edge and viability in the market arena (Bui \& Jones, 2006). Fast development of technologies, economic globalization and many other external circumstances stimulate changes in marketing environment. For the company to gain competitive edge in today's market, especially in the electronic market, it must have a good knowledge of the external environment, especially in technological environment that affects business operations. It is important for the company to know and predict environmental conditions that influence marketing activities. Some of the external factors that influence marketing activities of modern companies include; political, economic, social-cultural, and technological factors (Adam, Mulye,Deans \& Palihawadana, 2002). The study used descriptive cross sectional census survey. The design is appropriate since all the units of interest were investigated. Comparative analysis amongst all the units was done and the phenomenon under the study described as they appear to be satisfactory. From the findings, it was established that the performance of commercial banks is affected by the electronic marketing strategies selected by the bank. There is a rapid development in technology and hence banks are not being left behind in the adoption of new technology, due to either pressure from customers, stiff competition or change in technology. The banks performance is affected by electronic marketing strategies selected. The banks which have adopted the electronic marketing strategies, the performance is improved, banks which have not yet adopted the electronic marketing strategies are struggling in the performance. The banking sector should embrace electronic marketing strategy in order to survive in the rapidly changing markets.
\end{abstract}

JEL: G21; D20; D83

Keywords: electronic marketing, organizational performance, marketing strategies, digital media communication, channels, online partnerships

i Correspondence: email gacherirose93@gmail.com 


\section{Introduction}

The evolution and direction of any marketing strategy in local and international environments has forced firms to adopt electronic marketing strategies to gain competitive edge and viability in the market arena (Bui \& Jones, 2006). Fast development of technologies, economic globalization and many other external circumstances stimulate changes in marketing environment. For the company to gain competitive edge in today's market, especially in the electronic market, it has to have a good knowledge of the external environment, especially in technological environment that affects business operations. It is important for the company to know and predict environmental conditions that influence marketing activities. Some of the external factors that influence marketing activities of modern companies include; political, economic, social-cultural, and technological factors (Adam, Mulye, Deans \& Palihawadana, 2002).

Today's market grows incredibly fast. New ideas, structures, standards and necessities spread in the way, it happened earlier with all the vogues. Such a rate is determined by a possibility of communicating with the help of technology, not tied to geographic locations and the formation of consumers' continued desire for the newest, best, most stylish, smaller and faster devices (Flavián \& Guinalíu, 2006). Once a product enters the same market, it passes into the other. Each new future technology is much better than its predecessor. As soon as something new and revolutionary appears on the market, it is immediately being desired by the use of electronic marketing strategies (Dervenoael, Soopramanien, Elms \& Hallsworth, 2006).

One of major trends in today's marketing is orientation on exploitation of Internet and social media for promoting of the company and its products (Fillis, Johannson \& Wagner, 2004). Industrial and technological convergence, extinction of physical constraints, changes in consumer and retailer needs, competitors that turn up from previously non-market sectors, makes it much more complex of for businesses to survive (Darby, Jones \& Madani, 2003). Electronic marketing refers to the application of marketing principles and techniques via electronic media and more specifically the Internet. Electronic marketing is the process of marketing a brand on the Internet. It includes both direct response marketing and indirect marketing elements and uses a range of technologies to help connect businesses to their customers. Electronic marketing encompasses all the activities a business conducts via the worldwide web with the aim of attracting new business, retaining current business and developing its brand identity (Adam, Mulye, Deans \& Palihawadana, 2002).

\subsection{The Concept of E-Marketing}

Electronic Marketing can be viewed as a new philosophy of the $21^{\text {st }}$ century and a modern business tactic involved with the marketing of goods, services, information and ideas via the worldwide web and other electronic means. It involves the use of electronic data and applications for planning and executing the conception, distribution and pricing of ideas, goods and services to create exchanges that satisfy individual and organizational goals 
(Gatticker, Perlusz \& Bohmann, 2000). Electronic marketing is growing to be more attractive as firms are utilizing the opportunities the technology is offering.

E-marketing is essentially a subset of marketing (Fisks, 2009). Electronic marketing is one aspect of an organizational function and a set of processes for creating, communicating and delivering value to customers, and for managing customer relationships in ways that benefit the organization and its stakeholders using electronic means (Goldsmith \& Lafferty, 2002). As such an aspect, e-Marketing has its own tools and approaches that contribute to the realization of marketing objectives. Electronic marketing aids companies to deliver value added products and services in the market. Benefits of electronic marketing include; speedy access, reaching a wider market, efficient use of buyer time, connecting to specific customers, no limitations on content, world-class showcase, easy management, efficient use of technology, savings on costs, simple to use, and a continuous availability (Hinson \& Sorensen, 2006).

Correct implementations of electronic marketing strategy enable organizations to perform effectively and efficiently all areas of operation. It provide opportunities of maximizing returns on investment, promote stakeholder relations between customers, suppliers, investors, and competitors, increase profits, volume of sales, market share, development of new products, and communication within and outside the organization. E-marketing provides faster exchange of information, but successful employment of information raises the effectiveness and profitability of an organization (Reedy \& Zimmerman, 2000).

\subsection{The Concept of Electronic Marketing Strategies}

Traditional approaches of communication are being replaced by modern electronic technology including e-banking and social media networks that are enabled by internet connectivity. The internet has changed completely ways in which individuals and organizations buy and sell products and services. Consumers now use the internet to research and purchase products/services on the internet. Organization now requires electronic marketing strategies to attract and retain customers.

The electronic marketing strategies applied by organizations to cope with competition include; e-place, e-product, e-promotion and e-pricing strategies. Organizations apply electronic marketing strategies to minimize costs and maximize profits in the long run.

\subsection{The Concept of Organizational Performance}

Organizational performance entails the actual results of an organization as measured against its anticipated expectations. It involves the ability of an organization to fulfill its vision and mission through strong governance, proper management and a persistent dedication to achieving results. Effective nonprofits are mission-driven, adaptable, customer-focused, entrepreneurial, outcomes oriented and sustainable. Creating flexible, high-performing, learning organizations is the secret to gaining competitive advantage in a world that won't stand still (Pickton \& Broderick, 2001). 
Organizational performance encompasses accumulated end results of all the organization's work processes and activities. Performance measures can be financial or non-financial. Both measures are used for competitive firms in the dynamic business environment. Financial measures of organizational performance include; return on assets, return on sales, return on equity, return on investment, return on capital employed and sales growth. Non-financial organizational performance measures include; webperformance track variations in traffic page views, advertising impressions served and unique users.

The foundation of long-term performance is lifetime customer value; the revenue customers generate over their lives, less the cost of acquiring, converting, and retaining them. Web marketing strategy using the $4 w$ 's will result in an increase in efficiency within established marketing functions (Goldsmith \& Lafferty, 2002). Second, the technology of e-marketing transforms many marketing strategies resulting in new business models that add customer value or increase company profitability. Focusing on web performance many e-commerce companies collect data related to cost and usage of their websites, few of them understand, in detail, how well such information measures their sites' performance or how this performance compares with that of competing sites (Adam, Mulye, Deans \& Palihawadana, 2002).

\subsection{The Banking Industry in Kenya}

The banking sector in Kenya dating back to 1689 provides financial services to the lowincome households and micro and small enterprises thus contribute to poverty alleviation.

The Companies Act, the Banking Act, the Central Bank of Kenya Act and the various prudential guidelines issued by the Central Bank of Kenya (CBK, 2012), governs the Banking industry in Kenya. The banking sector was liberalized in 1995 and exchange controls lifted. The CBK, which falls under the Minister for Finance's docket, is responsible for formulating and implementing monetary policy and fostering the liquidity, solvency and proper functioning of the financial system. The CBK publishes information on Kenya's commercial banks and non-banking financial institutions, interest rates and other publications and guidelines. The banks have come together under the Kenya Bankers Association (KBA), which serves as a lobby for the banks' interests and addresses issues affecting its members (CBK, 2012).

According to the Central Bank of Kenya, there are 43 licensed commercial banks in Kenya. Three of the banks are public financial institutions with majority shareholding being the government and state corporations. The rest are private financial institutions. Of the private banks, 27 are local commercial banks while 13 are foreign commercial banks. Commercial banks in Kenya play a major role in Kenya.

They contribute to economic growth of the country by making funds available for investors to borrow as well as financial deepening in the country. Commercial banks therefore have a key role in the financial sector and to the whole economy (CBK, 2012). 
Due to changing business environment and consumer needs, commercial banks in Kenya are faced by the challenge of attracting and retaining customers. Technology has remained strategic tool of marketing commercial banks services locally and internationally. The extent of adoption of electronic marketing strategies on the performance of commercial banks in Kenya has remained a challenge due to employee resistance to change, inadequate management support through staff training and stiff competition from global firms.

\section{Problem Statement}

Due to changing external business environment characterized by globalization and new technologies in marketing of products and services, electronic marketing has become the modern approach that companies are using to attract, retain and maintain customer relations to gain competitive edge in the dynamic business environment (Dervenoael, Soopramanien, Elms \& Hallsworth, 2006). Change of consumer tastes and preferences in the market, electronic marketing has become the driving force of competitive companies in the global market. Small and large organizations need to adopt electronic marketing strategies to gain competitive edge against their competitors in the market.

Companies that have successfully implemented electronic marketing strategies have distinguished performance in the market. Some of the benefits include; increased profits, volume of sales, market share quality service delivery to customers without delay, minimal costs of production, marketing and distribution and new product development (Jutla, Bodorik \& Dhaliwal, 2002). On the other hand, it is evident that electronic marketing concept is a new concept in developing countries of the world due to various challenges including inadequate infrastructure to support the concept in all sectors of the economy. Financial institutions both in developed and developing countries have to adopt electronic marketing strategies to gain competitive advantage in the changing marketing environment (Hinson \& Sorensen, 2006).

Commercial Banks in Kenya are facing stiff competition from international and local players in the financial industry. Electronic marketing strategies have become one of the drivers of their businesses locally and internationally. It is evident that regardless, the benefits associated with the adoption of electronic marketing, most of the commercial banks in Kenya are experiencing challenges that has hindered their performance.

A study carried out by Kiprotich (2012) on the relationship of e-commerce practices and performance of micro finance institutions in Kenya, identified that ecommerce is the most effective and efficient marketing strategy of modern firms regardless of its challenge of adoption in the organization. Also, a study by Ondati (2011) on the influence of technology on the performance of manufacturing in Kenya identified that technology is the only strategy companies can use to enter global markets and outshine their competitors.

A study by Nyangosi (2008) on E-Banking: An Integration Technology in Kenya shows that majority of banks have introduced internet banking, mobile banking and 
other e-banking facilities, to enhance delivery channels to their customers. It is however, important that the introduction of these products be accompanied with programs to broaden consumer horizon by enhancing their knowledge in the new and more innovative way of conducting banking business. Not many banks have embraced ebanking but majority have at least one or two technology based delivery channels. The non-adoption of e-banking by banks has been attributed to impaired non-availability of infrastructure and legislation to support e-banking. Another study by Ochieng (2006) on adoption of e-commerce strategies on performance of Commercial Banks in Kenya identified that banks are faced with a number of important questions, for examples how to take full advantage of new technology opportunities and how e-developments change the ways customers interact with the financial institution.

However, it is evident that from the findings of the previous studies, adoption of electronic marketing still remains a big challenge to Commercial Banks in Kenya. Previous studies that have been carried out did not focus on electronic marketing strategies in relation to performance of Commercial Banks; the studies carried out focused in different sectors and were too general. Therefore, it is for this reason this study seeks to investigate the influence of electronic marketing strategies on the performance of Commercial Banks in Kenya.

The study was guided by the following research questions; what is the relationship between electronic marketing strategies and performance of Commercial Banks in Kenya?

\subsection{Research Objectives}

The research objectives were:

- To determine how the use of internet as a marketing strategy helps equity bank to deal with competition and survival.

- To determine if the social media is pushing equity bank to profit maximization and lowering the cost of operation.

\subsection{Significance of the Study}

The findings of the study will be important to: Commercial Bank employees in Kenya as it will be able to assess whether the electronic marketing strategies adopted have been beneficial to them or not thus coming up with appropriate policies to minimize customer costs and maximize profits.

The government will be able to understand how Commercial Banks use electronic marketing strategies to gain competitive edge due to intense competition from local and foreign firms and hence their sustainability. The Government will be in a position to support internet supported initiatives to promote through fiber optic cable initiatives to promote all sectors of the economy.

It will be in a position to formulate policies that are aimed at increasing productivity and safeguarding their interests based on quality checks. 
The development partners who are usually interested at helping the Commercial Banks to prosper will have an understanding of a wide variety of factors that hinder them hence sustainability and the extent to which the identified factors affect their operations.

To scholars and researchers who would like to debate or carry out more studies on electronic marketing strategies can use the study as well. The study will form a basis upon which further research on the same will be based. The findings will enable the researchers understand the necessary resources which may be required in future related studies. The findings of the study will also be important to other firms, as it will provide information on how they engage with their clients.

\section{Research Methodology}

\subsection{Research Design}

This is a descriptive cross sectional census survey. The design is appropriate since all the units of interest were investigated. Comparative analysis amongst all the units was done and the phenomenon under the study described as they appear to be satisfactory.

\subsection{Population of Study}

The population of study was from equity bank branches licensed to operate in Nairobi by the Central Bank of Kenya.

\subsection{Data Collection}

Primary data was obtained using a semi-structured questionnaire. Respondents were the heads of marketing operations functions in the branches or an equivalent position as was directed by a particular branch. The questionnaire is divided into two sections. Section one is designed to obtain general information on the organization. Section two consists of questions directed to determine the influence that electronic marketing has on performance business wise. The questionnaire was administered through "drop and pick later" method.

\subsection{Data Analysis}

The data collected was checked for completeness and consistency. Factor analysis was used to rate each factor in the order of their significance. Each factor was checked against the tables, charts and graphs. Data analysis is the process of bringing order, structure and meaning to the mass of information collected. It involves examining what has been collected and making deductions and inferences (Kombo and Tromp, 2006). 


\section{Data Presentation and Discussion of Findings}

\subsection{Introduction}

This chapter presents the output of data analysis. The presentations are in form of tables and statements. The presentation is according to the objectives of the study and the hypotheses generated.

\subsection{Academic Level of Respondents}

The study sought and obtained details about the academic level of the respondents for purposes of understanding their role in the variables of study. Details of the respondents and their academic level are shown in Table 4.1 below.

Table 4.1: Academic Level of Respondents

\begin{tabular}{|l|c|c|}
\hline Academic Level of Respondents & Frequency & Percentage (\%) \\
\hline Master's degree & 1 & 2.6 \\
\hline First Degree & 21 & 50.2 \\
\hline 0-Level & 5 & 9.2 \\
\hline Diploma & 11 & 27.3 \\
\hline A-Level & 6 & 11.4 \\
\hline Total & 43 & 100 \\
\hline
\end{tabular}

Source: Research data.

As shown in Table 4.1,50\% of the respondents were degree holders working in the banks. $27 \%$ of them were diploma holders. $11 \%$ of them were A-level holders. $9 \%$ of them were O level holders and $3 \%$ of them were post-graduate holders.

\subsection{Period Employees Worked in the Bank}

Respondents were asked to indicate the period they had worked in the bank. The findings are summarized in Table 4.2.

Table 4.2: Period Employees Worked in the Bank

\begin{tabular}{|l|c|c|}
\hline Duration & Frequency & Percentage (\%) \\
\hline 6-10 years & 21 & 50.2 \\
\hline $11-15$ years & 1 & 2.6 \\
\hline 16-19 year & 5 & 9.2 \\
\hline Less than 5 years & 11 & 27.3 \\
\hline 20 and above years & 6 & 11.4 \\
\hline Total & 43 & 100 \\
\hline
\end{tabular}

Source: Research data.

As shown in Table 4.2, 50\% of the respondents had worked in their banks for a period of 6-10 years. $27 \%$ of them had worked for less than 5 years. $11 \%$ of them had worked for a period of 20 years and above. $9 \%$ of them had worked between $16-19$ years. $2 \%$ of them had worked for a period of 11-15 years. 


\subsection{Longevity of the Bank Operation}

Respondents were asked to indicate the period the bank had operated in the Kenyan markets. The findings are summarized in Table 4.3.

Table 4.3 Longevity of the Bank Operation

\begin{tabular}{|l|c|c|}
\hline Duration & Frequency & Percentage (\%) \\
\hline 11-15 years & 10.3 & 25.4 \\
\hline 6-10 years & 10.4 & 25.1 \\
\hline Less than 5 years & 8 & 20.1 \\
\hline Less than 5 years & 10.2 & 25.3 \\
\hline 20 and above years & 5 & 5.00 \\
\hline Total & 43 & 100 \\
\hline
\end{tabular}

Source: Research data.

As shown in Table 4.3, respondents said that the bank had operated in the Kenyan market for a period of 6-15 years. $25 \%$ of them indicated that they had operated for a period between 16-19 years and some (5\%) said they had operated for over 20 years.

\subsection{Bank Customer Base}

Respondents were asked to indicate the period the bank had operated in the Kenyan markets. The findings are summarized in Table 4.4 .

Table 4.4: Bank Customer Base

\begin{tabular}{|l|c|c|}
\hline Bank Customer Base & Frequency & Percentage (\%) \\
\hline $1,000,000$ and above & 13.3 & 27.4 \\
\hline Less 100,000 & 11.4 & 25.1 \\
\hline $500,000-1,000,000$ & 10.2 & 18.1 \\
\hline $100,000-500,000$ & 9.2 & 25.3 \\
\hline Total & 43 & 100 \\
\hline
\end{tabular}

Source: Research data.

The researcher sought to know the commercial bank customer base as described in Table $4.4,27 \%$ of the commercial banks were having a customer base of above $1,000,000.25 \%$ of them were having less 100,000. 25\% of them were having 100,000-500,000 customer base. $18 \%$ were having $500,000-1,000,000$ customers.

\subsection{E-marketing Strategies}

The study sought and obtained details about the E-marketing strategies that were used by commercial banks. Details of the respondents and E-marketing strategies used by banks are shown in Table 4.5 below. 
THE INFLUENCE OF ELECTRONIC MARKETING STRATEGIES

ON THE PERFORMANCE OF EQUITY BANK LIMITED IN KENYA

Table 4.5: E-marketing Strategies

\begin{tabular}{|l|c|c|c|c|c|}
\hline E-marketing Strategies & $\mathbf{N}$ & Min & Max & Mean & Std Deviation \\
\hline $\begin{array}{l}\text { Product promotion via online } \\
\text { catalog }\end{array}$ & 43 & 2 & 5 & 4.08 & .882 \\
\hline Online transaction processing & 43 & 2 & 5 & 4.08 & .882 \\
\hline $\begin{array}{l}\text { Electronic bills of lading } \\
\text { processing }\end{array}$ & 43 & 2 & 5 & 3.24 & .943 \\
\hline $\begin{array}{l}\text { Online collaborative work } \\
\text { interaction }\end{array}$ & 43 & 2 & 5 & 3.24 & .915 \\
\hline $\begin{array}{l}\text { Online Sales promotion and } \\
\text { advertising }\end{array}$ & 43 & 2 & 5 & 3.24 & .935 \\
\hline Online goods or services trading & 43 & 2 & 5 & 3.24 & 1.137 \\
\hline Online catalogs & 43 & 2 & 5 & 3.11 & 1.034 \\
\hline Online accounts settlement & 43 & 2 & 5 & 3.11 & 1.034 \\
\hline Online digital content delivery & 43 & 2 & 5 & 3.66 & .878 \\
\hline E-manufacturing management & 43 & 2 & 5 & 3.66 & .878 \\
\hline E-Inventory management & 43 & 2 & 5 & 3.66 & .878 \\
\hline Online sourcing & 43 & 2 & 5 & 3.66 & .878 \\
\hline Online public procurement & 43 & 2 & 5 & 3.66 & .878 \\
\hline Online Customer support & 43 & 2 & 5 & 3.66 & .878 \\
\hline Online post-sales service. & 43 & 2 & 5 & 3.66 & .878 \\
\hline Valid N (list wise) & 43 & & & & \\
\hline
\end{tabular}

Source: Research data.

As indicated in Table 4.5, respondents indicated that, product promotion via online catalogs and online transaction processing were e-marketing strategies that were used by the bank with a mean of (4.08). This was the drive of banks to minimize operational costs using modern technologies. As indicated in literature, both new and existing companies can reduce some costs for their firms such as the cost of printing the brochures, leaflets, or catalogue for introducing new products to the market. Most of services and communication are done over the Internet, so companies can decrease the number of staff in some departments, as the result they can lower the overhead costs (Darby, Jones \& Madani, 2003).

As indicated in Table 4.5 electronic bills of lading processing, online collaborative work interaction, online sales promotion and advertising and online goods or services trading were e- marketing strategies used by commercial banks with a mean of (3.4). They applied the strategies in order to have worldwide access of customers, provide services to customers all the time and have wider connectivity with the market. As indicated in literature, the age of information technology enables people to access the websites if they have Internet connection, no matter where they live in the world. Through that the audience can know the information about companies, their products, making the purchase or creating the contact with one another. Companies can launch a marketing campaign over the Internet, people from everywhere can see it if they access to the website (Jutla, Bodorik \& Dhaliwal, 2002). 
Marketing on the Internet can create more interactivity between companies and customers. People can give feedback about products and services by posting comment on the sites. Through a website people can focus on the specific information they want to see, rather than the general information from the television which advertises about companies and products. (Jutla, Bodorik \& Dhaliwal, 2002).

Online catalogs and online accounts settlement were e-marketing strategies used with a mean of (3.11). This was due to the ability of the bank to keep in touch with customers using digital communication channels and search engine marketing. As evident in literature, digital media communications channels and the proper use of these techniques together with a good website can help companies to draw the traffic as well as achieving the e-marketing objectives they have set up (Jutla, Bodorik \& Dhaliwal, 2002). Search engine marketing (SEM) is an important channel of e-marketing. It includes three main techniques such as Search engine optimization (SEO), Paid per Click (PPC) and Trusted feeds which includes Paid-for-inclusion. These elements of search engine marketing can help companies to increase their visibility on the search engine as well as spread their names to many people (Jutla, Bodorik \& Dhaliwal, 2002).

As indicated in Table 4.5 online digital content delivery, e-manufacturing management, e-inventory management online sourcing online public procurement, online customer support and online post-sales service were e- marketing strategies used by the bank with a mean of (3.66) as they provident opportunities of online public relations, online partnerships, interactive ads strategy, opt-in e-mail strategy and online viral marketing strategy. As evident in literature public relation is one marketing communication channel with the purpose to create, promote, maintain the goodwill, favorable image, and reputation for organization, brand, etc. toward different stakeholders. The goal of public relations is usually gained by the influence of the different media (Jutla, Bodorik \& Dhaliwal, 2002). The purpose of online PR is to enhance the awareness as well as "maximizing favorable mentions of your company, brands, products or websites on third party web sites which are likely to be visited by your target audience" (Hoffman \& Novak, 1996).

Online partnerships can take many forms. The best known methods are affiliate marketing, sponsorship, co-branding, link building and widget marketing. "Affiliate marketing is a commission based arrangement where the merchant pays a percentage or a fixed commission to the referring site (affiliate publisher) for each lead or sale delivered" Online sponsorship is "the linking of a brand with related content or con-text for the purpose of creating brand awareness and strengthening brand appeal in a form that is clearly distinguishable from a banner, button, or other standardized ad unit" (Goldsmith \& Lafferty, 2002).

The goal of online interactive advertising is also similar to the goals of traditional marketing (Fisks, 2009). A company uses those techniques as the ways to promote its new products or services to the potential customers. Some techniques used in interactive advertising are banner ads, skyscrapers, e-mail ads, pop-up ads, site sponsorships, rich media video \& audio, PPC search engine ads, keyword search or paid listings (Hinson \& Sorensen, 2006). 
A company obtains the e-mail ad-dresses of online audiences and sends e-mail to them when they agree to receive it. The e-mail is only sent when online audiences clearly subscribe to receive the news or information that they are interested in (Hinson \& Sorensen, 2006). Online viral marketing is a type of online word of mouth marketing. It is a clever idea to do e-marketing. Online viral marketing is various in contents, techniques and ways of delivering. The strategy is used to encourage people to pass the messages to others on the Internet. By taking advantage of online social networks like email, instant messages and chat rooms (Hinson \& Sorensen, 2006).

\subsection{Performance Measurements}

The respondents were asked to indicate performance measures their banks used. Details of the respondents and performance measures used by banks are shown in table 4.6.

Table 4.6: Performance Measurements

\begin{tabular}{|l|c|c|c|c|c|}
\hline Performance Measurements & N & Min & Max & Mean & Std Deviation \\
\hline Reduced costs of production & 43 & 1 & 5 & 4.00 & .900 \\
\hline Increased customer satisfaction & 43 & 2 & 5 & 4.00 & .921 \\
\hline Increased market share & 43 & 2 & 4 & 3.10 & .841 \\
\hline Increased profitability & 43 & 2 & 5 & 3.10 & .844 \\
\hline Introduction of new products & 43 & 1 & 4 & 3.11 & .789 \\
\hline Increased Job Satisfaction & 43 & 2 & 5 & 3.11 & .894 \\
\hline Minimal customer complaints & 43 & 2 & 5 & 2.68 & .789 \\
\hline $\begin{array}{l}\text { ICT integration in customer service } \\
\text { delivery }\end{array}$ & 43 & 2 & 4 & 2.68 & .852 \\
\hline Increased Departmental synergy & 43 & 2 & 5 & 2.68 & .878 \\
\hline Expansion into new markets & 43 & 1 & 4 & 2.68 & .882 \\
\hline Improved employee performance & 43 & 2 & 4 & 2.54 & 1.040 \\
\hline Increased return on investments & 43 & 2 & 5 & 2.54 & 1.040 \\
\hline Increased Crossfunctional trainings & 43 & 1 & 4 & 2.54 & 1.030 \\
\hline Low Employee turn over & 43 & 2 & 5 & 2.54 & 1.040 \\
\hline Valid N (list wise) & 43 & & & & \\
\hline
\end{tabular}

Source: Primary data.

As indicated in Table 4.6, respondents indicated that e-marketing strategies enabled commercial banks to perform in the market thus competitive edge based on reduced costs of production and increase customer satisfaction with a mean of (4.00). Increased market share and profitability were ranked second with a mean of (3.10). Introduction of new products and increased job satisfactions were ranked third measures of performance with a mean of (3.11). Minimal customer complaints, ICT integration in customer service delivery, increased departmental synergy, expansion into new markets were measures of performance that were ranked fourth with commercial banks with a mean of (2.68). Finally, respondents indicated that improved employee performance, increased return on investments, cross functional training and low employee turnover were measures of commercial bank performance with a mean of (3.54). 


\subsection{Relationship between electronic marketing strategies and performance of Equity bank LTD}

This section answers objective two of the study. The relationship between electronic marketing strategies and performance of commercial banks was investigated using Eproduct strategies, E-price strategies, E-place strategies and E-promotion strategies as dimensions for Commercial Bank Performance.

Table 4.7: Pearson's Correlation Analysis

\begin{tabular}{|l|c|c|c|c|}
\hline & $\mathbf{1}$ & $\mathbf{2}$ & $\mathbf{3}$ & $\mathbf{4}$ \\
\hline E-product strategies, & 1 & & & \\
\hline E-price strategies & $0.217^{*}$ & 1 & & \\
\hline E-place strategies & $0.301^{* *}$ & $0.502^{*}$ & 1 & \\
\hline E-promotion strategies & $0.294^{* *}$ & $0.091^{*}$ & $0.291^{*}$ & 1 \\
\hline Reporting & $0.276^{* *}$ & $0.389^{* *}$ & $0.299^{* *}$ & $0.179^{* *}$ \\
\hline
\end{tabular}

** $\sigma=0.01$ (correlation is significant at 0.01 level (2-tailed) * $\sigma=0.05$ (Correlation is significant at 0.05 level (2tailed).

The correlation table presents the relationship between dimensions of equity Bank Performance measured by E-product strategies, E-price strategies, E-place strategies, Epromotion strategies and Reporting. The results show that all the dimensions relate positively. Specifically, E-price strategies, E-place strategies, E-promotion strategies and reporting $(\mathrm{r}=0.294, \mathrm{p}<0.01 ; \mathrm{r}=0.338, \mathrm{p}<0.01 ; \mathrm{r}=0.276, \mathrm{p}<0.01)$ respectively. These suggest that the e-marketing strategies relates positively with commercial bank performance.

\subsection{E-marketing strategies and equity bank performance}

Table 4.7 above shows that the e-marketing strategies is positively related to E-promotion strategies with $\mathrm{r}=0.294$ and standard error, $\mathrm{p}<0.01$, E-place strategies is positively related with commercial bank performance with $r=0.301$ and standard error, $\mathrm{p}<0.01$, and E-price strategies is positively related to commercial bank performance reporting with $r=0.217$ and $p<0.01$. This suggests that the e-marketing strategies are related with commercial bank performance and therefore hypothesis one $(\mathrm{H} 1)$, there is a relationship between the e-marketing strategies and the performance of commercial banks in Kenya is accepted.

\section{Summary Findings, Conclusion and Recommendation}

\subsection{Introduction}

This chapter summarizes the major findings of this study. This study sought to find out the influence of electronic marketing strategies on the performance of commercial banks in Kenya. In addition, this chapter provides a direction for further studies and also gives some recommendations for policy making by the relevant authorities. Questionnaires were used to gather primary data. The questionnaires comprised of both closed and 
open-ended questions and were strictly administered by the researcher. Both primary and secondary information was used to determine the results findings of the study.

\subsection{Summary and Findings}

To gain competitive edge in the dynamic business environment, large and small firms should adopt e-marketing strategies for survival. To achieve objectives like profit maximization, offsetting costs of operations, business survival and gaining competitive advantage in the market, e-product strategy, e-pricing e-strategy, e-promotion e-strategy, e-distribution strategy are drivers of the dynamic market.

The study established that, to a certain extent most equity bank applied electronic marketing strategies with an aim of reaching customers globally and cutting down operational costs. Some of the electronic marketing strategies that they adopted include; Product promotion via online catalogs, online transaction processing, electronic bills of lading processing, online collaborative work interaction, online sales promotion and advertising, online goods or services trading and online catalogs.

The study established that equity bank adopted electronic marketing on a smaller extent due to technological challenge of the internal systems, staff, and inadequate management support. Some of these electronic strategies include; online accounts settlement, online digital content delivery, e-manufacturing management, e-inventory management, online sourcing, online public procurement, online customer support and online post-sales service. It was also established that resistance by employees to accept new technologies in customer service was a major challenge.

The study established that electronic marketing strategies have contributed to improved performance of commercial banks in terms of, reduced costs of production, increased customer satisfaction, increased market share, profitability, introduction of new products and increased job satisfaction. Therefore, technology is the driver of competitive companies in the dynamic marketing environment. The study established that, there is a relationship between the e-marketing strategies and the performance of commercial banks in Kenya. The influence of e-product, e-pricing, e-promotion and edistribution contribute to improved performance of commercial banks in Kenya.

\subsection{Discussions}

E-marketing has remained the driver of competitive companies in local and international markets. (Fisks, 2009). It help companies to outsmart their competitors by creating, communicating and delivering value to customers, and for managing customer relationships in ways that benefit the organization and its stakeholders using electronic means (Goldsmith \& Lafferty, 2002).

E-marketing has its own approaches and tools that contribute to the achievement of marketing goals and objectives. It helps companies to offer value added products and services in the domestic and global market. Benefits of electronic marketing are; speedy access, track able, reaching a wider public, efficient use of buyer time, connecting to specific audiences, no restrictions on content, world-wide showcase, easy to manage, 
efficient use of technology, modern touch, savings in postal charges, simple to use, and 24/7 availability (Hinson \& Sorensen, 2006).

Effective implementations of electronic marketing strategy enable organizations to perform effectively and efficiently all areas of operation. It provides opportunities of maximizing returns on investment, promote stakeholder relations between customers, suppliers, investors, and competitors, increase profits, volume of sales, market share, development of new products, and communication within and outside the organization. It also provides faster exchange of information between the company and the customer (Reedy \& Zimmerman, 2000).

\subsection{Conclusions}

The findings indicate that commercial banks endeavor to achieve some competitive advantage over their competitors in such a stormy environment by using different emarketing strategies which include; e-product strategy, e-pricing strategy, e-promotion strategy and e-distribution strategy. It is concluded that if a proper mechanism is put in place with regard to investment in e-marketing strategies by commercial banks operating in Kenya, commercial banks will gain competitive advantage in the market thus contributing to social economic developments in Kenya. Training of commercial bank staff, capital advancement and in reasonable terms, good business operating environment and good business practices, the banking industry will contribute to social economic developments of the Kenyan people.

From the findings, it was established that the performance of commercial banks is affected by the electronic marketing strategies selected by the bank. There is a rapid development in technology and hence banks are not being left behind in the adoption of new technology, due to either pressure from customers, stiff competition or change in technology. The banks performance is affected by electronic marketing strategies selected. The banks which have adopted the electronic marketing strategies, the performance is improved, banks which have not yet adopted the electronic marketing strategies are struggling in the performance. The banking sector should embrace electronic marketing strategy in order to survive in the rapidly changing markets.

\subsection{Recommendations}

The study established that commercial banks adopted electronic marketing on a smaller extent due to the influence of internal and external factors. Therefore, this study recommends timely training of commercial bank staff on electronic marketing practices. Integration of modern technologies in the organization sub-systems for efficiency and effectiveness. Management should allocate enough resources to empower the initiative within the organization thus minimal resistance from employees.

The Government of Kenya should formulate and implement policies that support small and large companies to use e-commerce platform to buy and sell their products and services through online thus globalization. 
Policy makers should regulate and provide or develop policies that will facilitate easy adoption of e-marketing in the banking sector. The policy makers should implement policies that will protect and attract more banks to adopt e-marketing strategy in order to improve economic performance not only of banks but of the country as a whole. The study confined itself to Equity bank in Kenya. This research therefore should be replicated in all other financial institutions especially micro finance institutions, savings banks and the results be compared so as to establish whether there is consistency in the performance of all financial institutions as a result of e-marketing.

\section{Conflict of Interest Statement}

The author declares no conflicts of interests.

\section{About the Author}

Rose Ndegwa is a Lecturer in Meru University in Kenya. A researcher in various fields like communication in the corporate world; psychology; matters gender and equity; et alia.

\section{References}

Alexander, J. H., Schouten, J. W., Koenig, H. F. (2002). Building Brand Community, Journal of Marketing, Vol. 66 No. January, pp.38-54

Adam, S., Mulye, R., Deans, K. \& Palihawadana, D. (2002). E-marketing in perspective: A three country comparison of business use of the Internet. Marketing Intelligence \& Planning, 20 (4): 243 - 251.

Belch, G., and Belch, M. A. (2003). Measuring the Effectiveness of Promotional Programs, Advertising and Promotion - An Integrated Marketing Communication Perspective, Tata McGraw Hill, New Delhi, 6th Edition.

Bui, T. X., Le, T. and Jones, W. D. (2006). An Exploratory Case Study E-Marketing in Ho Chi Minh City, Thunderbird International Business Review, 48(3) 369-388.

Buzzell, R. D. (2004). The PIMS Program of Strategy Research: A Retrospective Appraisal, Journal of Business Research, 57 (May), 478-83.

Chaston, I. \& Mangles, T. (2003). Relationship marketing in online business-to-business markets: A pilot investigation of small UK manufacturing firms. European Journal of Marketing, 37 (5/6): 753 - 773

Central Bank of Kenya (2010). Central Bank of Kenya Report

Collins, C., Buhalis, D. \& Peters, M. (2003). Enhancing SMTEs' business performance through the Internet and e-learning platforms. Education + Training, 45 (8/9): 483 $-494$

Darby, R., Jones, J. \& A. L. Madani, G. (2003). E-commerce marketing: fad or fiction? Management competency in mastering emerging technology. An international case analysis in the UAE. Logistics Information Management, 16 (2): 106 - 113. 
De Dervenoael, R., Soopramanien, D., Elms, J. \& Hallsworth, A. (2006). Exploring value through integrated service solutions: The case of e-grocery shopping. Managing Service Quality, 16 (2): 185 - 202

Fillis, I., Johannson, U. \& Wagner, B. (2004). Factors impacting on e-business adoption and development in the smaller firm. International Journal of Entrepreneurial Behaviour \&amp, 10 (3): 178 - 191

Flavián, C. \& Guinalíu, M. (2006). Consumer trust, perceived security and privacy policy: Three basic elements of loyalty to a web site. Industrial Management \& amp, 106 (5): 601 620

http://www.customessaymeister.com/customessays/Economy/4336.htm (20.10.2010).

Fisks, P. (2009). Mārketinga ăenijs. Rīga: “JāHa Rozes apgāds”.

Gatticker, U., Perlusz, S. and Bohmann, K. (2000). Using the Internet for B to B activities: A review and future direction for research, Internet Research: Electronic Networking Applications and Policy, 10 (2): 126 - 140. Goldsmith, R. \& Lafferty, B. (2002). Consumer response to Web sites and their influence on advertising effectiveness. Internet Research, 12 (4): 318 - 328

Bloomberg - Are you a robot?. (2021). Retrieved 17 June 2021, from http://www.businessweek.com/1998/23/b3581001.htm

Hart J., Daoust B. (2006). Blueprints For Success: eMarketing. Pleasanton: Blueprint Books. Hinson, R. \& Sorensen, O. (2006). E-business and small Ghanaian exporters: Preliminary micro firm explorations in the light of a digital divide. Online Information Review, 30 (2): 116-138.

Hoffman, D. and Novak, T. (1996). A new Marketing Paradigm for Electronic Commerce, The information Society, 13 (1): 43-54.

Hoffman, D. and Novak, T. (1996). Marketing in Hypermedia computer-mediated environment: Conceptual foundation, Journal of Marketing, 60 (July): 50-58.

Jutla, D., Bodorik, P. \& Dhaliwal, J. (2002). Supporting the e-business readiness of small and medium-sized enterprises: approaches and metrics. Internet Research, 12 (2): $139-164$

Kotler, P., Jain, D., Maesincee, S. (2000). Marketing Moves a New Approach to Profits, Growth, and Renewal. Harvard: Harvard Business School Publishing Corporation.

Kiprotich M. (2012). The Relationship of E-commerce Practices and Performance of Microfinance Institutions in Kenya. Unpublished MBA project. University of Nairobi.

Ondati K. (2011). The influence of Technology on the Performance of Manufacturing in Kenya. Unpublished MBA project. University of Nairobi

Ochieng. D. (2006). Adoption of E-commerce Strategies on Performance of Commercial Banks in Kenya. Unpublished MBA project. University of Nairobi

Mugenda, O.M., \& Mugenda A.G. (2003). Research Methods: Quantitative and Qualitative Approaches, African Centre of Technology Studies, Nairobi 
Pickton, D., \& Broderick, A. (2001). Integrated Marketing Communications. Financial Times Prentice Hall. https://d1wqtxts1xzle7.cloudfront.net/51601641/DavidPickton-Amanda-Broderick-Integrated-Marketing-Communications-2005-withcover-page-

v2.pdf?Expires=1623946822\&Signature=T3NaDBN1BQ3edM5EUgpwwDlZnCb9 VS3ewad8BI-NkMKnyCSBXgmpQoJ2T-WSGCnNm -sfz-

TUlyRxdBmrlXDFA0kIALfUqav6ShySrJFb36DsgiLLD4fJUVowFV3Opp6 QGEVIVr7mA5HyZXkMwNy8bPyC3ThX9L7v7AaEnrmhl9W3oMavGI pS OASF6eKVBc0lyHyedIXopwCTmlXxSlQZlv7iz9L72FxTczEYAj4nMR riqEzx TpW5K0LO4GdYUkvE0ZDFHsT7RqgjOVwkMl8UWE67IorMzASD5fV citVO02OvUUPT0iryQXol31AcfECEoa3geMCH32aT8rQ \&Key-PairId=APKAJLOHF5GGSLRBV4ZA (13.01.2010).

Reedy, J., Schullo, S., Zimmerman, K. (2000). Electronic Marketing: Integrating Electronic Resources into the Marketing Process. Orlando: Harcourt College Publishers, FL.

Richard Nyangosi (2007). E-Banking: An Integration Technology in Kenya. Guru Nanak Dev University, Amritsar Siliffš, A. Inovatīva domāšana. Rīga: SIA "Lietišèās informācijas dienests".

Saunders, M., Lewis, P., \& Thornhill, A. (2009). Research Methods for Business Students, 5 th Ed. New Jersey: Prentice Hall

Yates, D. S., Moore, D. S., \& Starnes, D. S. (2008). The Practice of Statistics, 3rd Ed. Freeman. 

applied to their work. Under the terms of this license, no permission is required from the author(s) or publisher for members of the community to copy, distribute, transmit or adapt the article content, providing a proper, prominent and unambiguous attribution to the authors in a manner that makes clear that the materials are being reused under permission of a Creative Commons License. Views, opinions and conclusions expressed in this research article are views, opinions and conclusions of the author(s). Open Access Publishing Group and European Journal of Economic and Financial Research shall not be responsible or answerable for any loss, damage or liability caused in relation to/arising out of conflict of interests, copyright violations and inappropriate or inaccurate use of any kind content related or integrated on the research work. All the published works are meeting the Open Access Publishing requirements and can be freely accessed, shared, modified, distributed and used in educational, commercial and non-commercial purposes under a Creative Commons Attribution 4.0 International License (CC BY 4.0). 